\title{
Extralevator Abdominoperineal Resection in the Prone Position
}

\author{
Young Jin Kim \\ Colorectal Cancer Clinic, Department of Surgery, Chonnam National University Medical School, Gwangju, Korea
}

\section{See Article on Page 12-19}

The conventional abdominoperineal resection (APR) has been the gold standard for the surgical treatment of low rectal cancer. Regardless of the approach, the APR represented a uniquely challenging procedure where the surgeon is expected to reduce the circumferential resection margin (CRM), local recurrence (LR) and wound complications. For cancer patients, excision of the anal canal with a wide circumferential margin, including a cylindrical cuff of the levator, muscle was introduced.

As described by West et al. [1], compared with standard surgery, the extralevator APR (ELAPR) may reduce CRM involvement (from $49.6 \%$ to $20.3 \%, \mathrm{P}<0.001$ ) and intraoperative perforation (IOP) (from $28.2 \%$ to $8.2 \%, \mathrm{P}<0.001$ ), but with an increase in perineal wound complications (from $20 \%$ to $38.0 \%, P=0.019$ ). In contrast, they did not demonstrate the statistically differences in $\mathrm{CRMs}$ and wound complications between the groups. A metaanalysis study by De Nardi et al. [2] found significant differences in the CRM involvement rate (odds ratio [OR], 2.9; $\mathrm{P}<0.001$ ), intraoperative perforation $(\mathrm{OR}, 4.30 ; \mathrm{P}<0.001)$, local recurrence rate $(\mathrm{OR}, 2.52 ; \mathrm{P}=0.02)$, and length of hospital stay $(\mathrm{OR}, 1.06$; $\mathrm{P}<0.001)$ in favor of the ELAPR group. Additionally, perineal wound complications were higher in the extended group (OR, $0.62 ; \mathrm{P}=0.007$ ). Yang et al. [3] reported that ELAPR had a lower rate of intraoperative perforation and local recurrence than APR in terms of short follow-up time. Yang et al. [4] reported better results in laparoscopic ELAPR: a 6.1\% CRM rate, 15.2\% morbidity, and no mortality.

Correspondence to: Young Jin Kim, M.D.

Colorectal Cancer Clinic, Department of Surgery, Chonnam National University Medical School, 322 Seoyang-ro, Hwasun-eup, Hwasun-gun, Jeollanam-do 58128 Korea

Tel: +82-61-379-7642, Fax: +82-61-379-7661

E-mail: kimyjin@jnu.ac.kr

(c) 2016 The Korean Society of Coloproctology

This is an open-access article distributed under the terms of the Creative Commons Attribution NonCommercial License (http://creativecommons.org/licenses/by-nc/4.0) which permits unrestricted noncommercial use, distribution, and reproduction in any medium, provided the original work is properly cited.
The perineal dissection can be performed in the lithotomy position or in the prone position after closure of the abdomen and creation of the colostomy. The author [5] reported that compared to the conventional APR, the ELAPR in the prone position did not have advantages in terms of perioperative complications and pathologic outcomes such as the CRM. In my opinion, the ELAPR in the prone position for treating patients with lower rectal or locally-recurrent pelvic cancer allows better exposure of the operative field and more precise perineal dissection according to the tissue plane and leaves open the possibility of an en-bloc combined resection of the sacrum or coccyx in difficult cases with sacral invasion. However, we need further randomized controlled studies to clearly identify the advantages and the disadvantages of the ELAPR in the prone position.

\section{CONFLICT OF INTEREST}

No potential conflict of interest relevant to this article was reported.

\section{REFERENCES}

1. West NP, Anderin C, Smith KJ, Holm T, Quirke P; European Extralevator Abdominoperineal Excision Study Group. Multicentre experience with extralevator abdominoperineal excision for low rectal cancer. Br J Surg 2010;97:588-99.

2. De Nardi P, Summo V, Vignali A, Capretti G. Standard versus extralevator abdominoperineal low rectal cancer excision outcomes: a systematic review and meta-analysis. Ann Surg Oncol 2015;22: 2997-3006.

3. Yang Y, Xu H, Shang Z, Chen S, Chen F, Deng Q, et al. Outcome of extralevator abdominoperineal excision over conventional abdominoperineal excision for low rectal tumor: a meta-analysis. Int J Clin Exp Med 2015;8:14855-62.

4. Yang X, Jin C, Deng X, Wang M, Zhang Y, Wei M, et al. Laparoscopic Extralevator abdominoperineal excision of the rectum with primary suturing: short-term outcomes from single-institution study. J Laparoendosc Adv Surg Tech A 2016;26:40-6.

5. Park S, Hur H, Min BS, Kim NK. Short-term outcomes of extral- 


\section{Coloproctology}

Young Jin Kim

evator abdominoperineal resection in the prone position compared with conventional abdominoperineal resection for ad- vanced low rectal cancer: the early experience at a single insititution. Ann Coloproctol 2016;32:12-9. 